\title{
Time of Origin of Opioid Peptide- Containing Neurons in the Rat Hypothalamus
}

\author{
HENRY KHACHATURIAN, MICHAEL E. LEWIS, NORMAN E. ALESSI, AND \\ STANLEY J. WATSON
}

Mental Health Research Institute, University of Michigan, Ann Arbor, Michigan 48109

\begin{abstract}
By using a combined technique of immunocytochemistry and $\left.\left.\right|^{3} \mathrm{H}\right]$ thymidine autoradicgraphy, we have determined the "birth date" of opioid peptide-containing neurons in several hypothalamic nuclei and regions. These include proopiomelanocortin (POMC) neurons (represented by ACTH immunoreactivity) in the arcuate nucleus; dynorphin A neurons in the supraoptic and paraventricular nuclei and the lateral hypothalamic area; and leuenkephalin neurons in the periventricular, ventromedial, and medial mammillary nuclei, as well as in preoptic and perifornical areas. Arcuate POMC neurons were born very early in embryonic development, with peak heavy $\left[{ }^{3} \mathrm{H}\right]$ thymidine nuclear labelling occurring on embryonic day E12. Supraop tic and paraventricular dynorphin A neurons were also labelled relatively early (peak at E13). The lateral hypothalamic dynorphin A neurons showed peak heavy labelling also on day E12. By contrast, leu-enkephalin neurons in the periventricular nucleus and medial preoptic area exhibited peak heavy nuclear labelling on day E14. Furthermore, perifornical and ventromedial leu-enkephalin neurons were also born relatively early (peak on days E12 and E13, respectively). However, the leu-enkephalin neurons in the medial mammillary nucleus were born the latest of all cell groups studied (i.e., peak at E15). The results indicate a differential genesis of these opioid peptide-containing neuronal groups in different hypothalamic nuclei and regions.
\end{abstract}

Key words: ACTH, dynorphin, enkephalin, neurogenesis, $\left[{ }^{3} \mathrm{H}\right]$ thymidine autoradiography

The existence of neuropeptides and neurotransmitters in the brain during early ontogenetic development has raised critical questions regarding the role of these substances in brain maturation as well as their functional capacity in the course of development (Coyle, '77; Lauder and Krebs, '78; Khachaturian and Sladek, '80; Swaab and Ter Borg, '81). For example, the presence of monoamines in embryonic brain prior to the establishment of synaptic neurotransmis sion has raised the possibility that these substances might act as neurotrophic agents in early ontogenesis (Olson and Seiger, '72; Seiger and Olson, '73), perhaps by regulating the onset of differentiation of cells in their projection areas (Lauder and Bloom '74; Lauder and Krebs, '76). Likewise, $\alpha$-melanocyte-stimulating hormone ( $\alpha$-MSH), a peptide derived from proopiomelanocortin (POMC), has been shown to stimulate brain development during late gestational periods (Swaab and Martin, '81).
The development and role of opioid and related peptides in brain processes during ontogenesis have only just begun to be addressed (Bayon et al., '79; Pickel et al., ' 82 ; Palmer et al., '82; Khachaturian et al., '83a; Alessi et al., '83; Alessi and Khachaturian, '85; Daikoku et al., '83; Schwartzberg and Nakane, '82). Biochemical studies of dissected regions have been useful in providing quantitative measures of opioid peptide content and form in different brain regions during maturation (Bayon et al., '79; Patey et al., '80; Alessi et al., '83; Alessi and Khachaturian, '85; Wardlaw and Frantz, '83). However, such studies are obviously limited in accurately pinpointing the location of neuronal cell bodies and their projections. Immunohistochemical studies have been successful in determining the location and matura-

Accepted February 14, 1985.

(C) 1985 ALAN R. LISS, INC. 
tional patterns of identified opioid neurons in different regions of the central nervous system (Pickel et al., '82; Khachaturian et al., 83a). Nevertheless, both anatomical and biochemical studies suffer from the limitations of the techniques used for detection of minute quantities of peptide. Thus, it is conceivable that at an early maturational stage, peptide synthesis occurs at such low rates that peptide content might fall below the sensitivity of the anti. serum used in radioimmunoassay or immunocytochemistry. However, the time of neuron genesis, whereby through a final mitotic division a neuroblast is formed and begins to differentiate into a neuron, can be determined by using a $\left[{ }^{3} \mathrm{H}\right]$ thymidine autoradiographic technique (see Sidman, '70). This technique accurately determines the time during gestation when a particular group of neurons is born, and has been used to study the time of origin of hypothalamic neurons (Ifft, '72; Shimada and Nakamura, '73; Altman and Bayer, '78a). Still, this "birth-dating" technique cannot account for the chemical identity of the neurons in question. In order to determine the chemical identity of specific neurons, Hoffman et al. ('80) combined [ $\left.{ }^{3} \mathrm{H}\right]$ thymidine autoradiography with immunocytochemistry to investigate the time or origin of somatostatin-containing neurons in the hypothalamus. In the present study, we have employed a similar immunocytochemical-autoradiographic technique to determine the time of genesis of opioid peptide-containing neurons in several hypothalamic nuclei (Khachaturian et al., '85).

\section{MATERIALS AND METHODS}

Adult male and female Sprague-Dawley rats were used in these experiments. At least 24 hours prior to mating, male rats were placed in large individual cages (one rat per cage) and kept under normal conditions. Three female rats were placed in each cage containing a male, before 6 P.M. At 8 A.M. the following day, vaginal smears were obtained from each of the females and examined under a microscope for live sperm. The presence of sperm was considered as indicative of conception, and that day was considered day zero of gestation (Khachaturian and Sladek, '80). The impregnated females were then placed in individual cages and also kept under normal conditions. Embryonic development was allowed to progess until day $12,13,14,15$, or 16 of gestation at which time three or more pregnant rats were selected at each particular gestational day for $\left[{ }^{3} \mathbf{H}\right]$ thymidine injection. At each embryonic day, E12 through E16, rats were injected with $7 \mu \mathrm{Ci} / \mathrm{g}$ body weight of $\left[{ }^{3} \mathrm{H}\right]$ thymidine (New England Nuclear) at a concentration of $1 \mathrm{mCi}$ / $\mathrm{ml}$ (specific activity $6.7 \mathrm{Ci} / \mathrm{mmol}$ ). Each rat received only one injection. Injected rats were returned to individually marked cages and kept under normal conditions. These rats were allowed to deliver, and the progeny to develop into young adults (approximately 6 weeks).

Three or more adult males were selected from each $\left[{ }^{3} \mathrm{H}\right]$ thymidine injection group (i.e., day E12 through E16), and each rat was anesthetized with sodium pentobarbital and injected intracerebroventricularly with $50-200 \mu \mathrm{g} / 10 \mu \mathrm{l}$ of colchicine to enhance immunocytochemical visualization of neuronal perikarya. At 24-48 hours after colchicine administration, each animal was anthesthetized by intraperitoneal injection of sodium pentobarbital, and the cardiovascular system was flushed with $50 \mathrm{ml}$ ice-cold $0.9 \%$ saline injected through the left ventricle. This was immediately followed by intraaortic perfusion for 30 minutes with ice-cold phosphate-buffered (pH 7.4) 4\% paraformalde- hyde at a pressure of $140 \mathrm{~mm} \mathrm{Hg}$. The brain was then removed and postfixed for an additional hour at $4^{\circ} \mathrm{C}$, stored in $15 \%$ sucrose overnight at $4^{\circ} \mathrm{C}$, and frozen in O.C.T. (Tissue Tek) embedding medium in liquid nitrogen. All tissues were stored at $-80^{\circ} \mathrm{C}$ prior to use. Brains were sectioned in a cryostat at $-20^{\circ} \mathrm{C}$ and thaw-mounted onto gelatin-coated slides.

\section{Immunocytochemistry}

The antisera used in the present study have been extensively characterized, each being highly specific for the corresponding peptide (Watson et al., '78; Khachaturian et al., ' 82 , '83b). The adrenocorticotrophic hormone (ACTH) antiserum specific for ACTH (20-24) can be blocked by ACTH (1-24), -1-39), -(11-24), but not by ACTH (11-19), $\alpha$-MSH, $\beta$-lipotropin, $\beta$-endorphin, or met-enkephalin. The anti-leuenkephalin serum can be blocked by leu-enkephalin, but not by BAM-22P, peptide E, dynorphin A (1-17), or $\beta$-endorphin. Lastly, the anti-dynorphin $A(1-17)$ serum can be blocked by dynorphin $\mathrm{A}(1-17)$ and dynorphin $\mathrm{A}(1-8)$, but not by dynorphin B (1-13), $\alpha$-neo-endorphin, leu-enke phalin, met-enkephalin, BAM-22P, peptide E, or $\beta$-endorphin.

For immunocytochemistry (Khachaturian et al., '82), slide-mounted tissues were allowed to air-dry at room temperature, after which they were incubated $\left(37^{\circ} \mathrm{C}\right)$ with primary antiserum. All antisera were diluted with $0.02 \mathrm{M}$ phosphate-buffered saline (PBS) in $0.3 \%$ triton X-100. After 1-hour incubation, the slides were transferred to moistboxes and stored for 24 hours at $4^{\circ} \mathrm{C}$. The second day, all tissues were washed in PBS and incubated $\left(37^{\circ} \mathrm{C}\right)$ for 30 minutes with goat antirabbit serum (Arnel). The slides were again stored for 24 hours at $4^{\circ} \mathrm{C}$. The third day, all tissues were washed in PBS and incubated for successive 40-minute periods (with PBS wash in between) with antihorseradish-peroxidase (anti-HRP) serum, followed by $4 \mu \mathrm{g} /$ ml HRP enzyme (Sigma, type V1). After PBS wash, the slide-mounted sections were treated with diaminobenzidine (Sigma) $(0.125 \mathrm{mg} / \mathrm{ml})$ in a solution of $0.03 \% \mathrm{H}_{2} \mathrm{O}_{2}$ for 15 minutes at room temperature. The slides were washed in distilled water and allowed to air dry.

\section{$\left[{ }^{3} \mathrm{H}\right]$ thymidine autoradiography}

For $\left[{ }^{3} \mathrm{H}\right]$ thymidine autoradiography (Langager et al., '82), the air-dried slide-mounted tissues (from the previous step) were individually dipped into a subbing solution made of 5 $\mathrm{mg} / \mathrm{ml}$ gelatin and $0.5 \mathrm{mg} / \mathrm{ml}$ chromium potassium sulfate and allowed to air-dry. Next, the dry sections were dipped into a solution of $0.01 \mathrm{~g} / \mathrm{ml}$ 2,5-diphenoxazole (PPO) in 95\% ethanol and allowed to air-dry once more. The slides were then transferred to a darkroom equipped with a Thomas Super Safelight, individually dipped into Kodak NTB-2 emulsion (at $41^{\circ} \mathrm{C}$ ), and allowed to air-dry upright for 2 hours in complete darkness. The slides were stored in light-tight slide boxes containing Drierite at $80^{\circ} \mathrm{C}$ for 1 week, after which the slides were developed in Kodak D-19 developer at $16-17^{\circ} \mathrm{C}$, fixed in Kodak Rapidfix, and washed in distilled water. The sections were dehydrated through graded ethanols and xylenes and coverslipped in Permount.

\section{Cell counts}

With a Leitz Orthoplan microscope, immunoreactive cells in a specific hypothalamic nucleus were counted in several sections. The nuclear boundaries were determined using adjacent Nissl-stained sections. Immunoreactive $\mathrm{ACTH}$ 
containing perikarya were counted in the arcuate nucleus (Fig. 1A). Dynorphin A immunoreactive perikarya were counted in the magnocellular supraoptic (Fig. 1B) and paraventricular nuclei, as were those scattered in the lateral hypothalamic area. Immunoreactive leu-enkephalinergic neuronal perikarya were counted in the periventricular
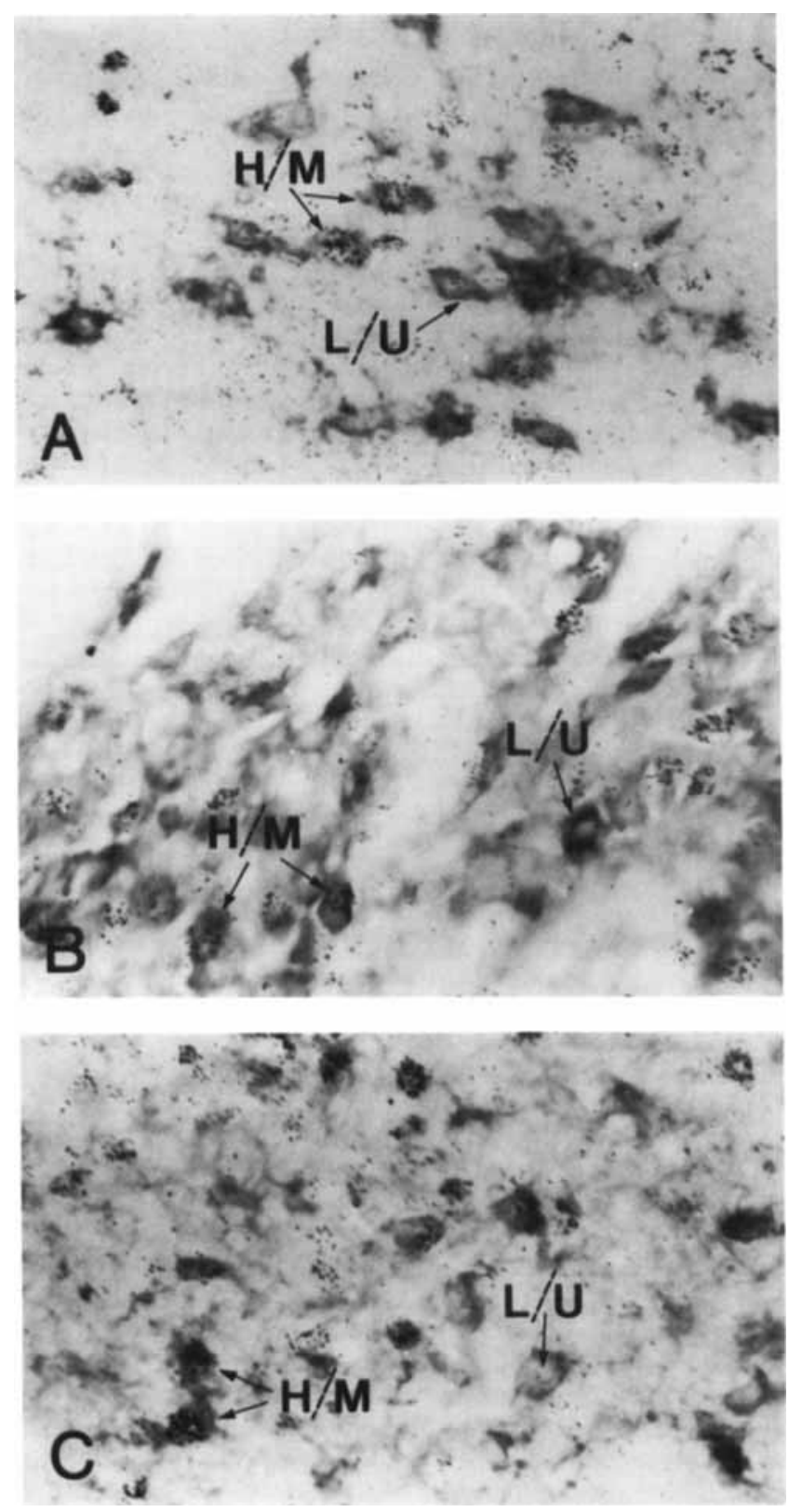

Fig. 1. Representative hypothalamic nuclei from each opioid peptidecontaining cell group under investigation. A. ACTH immunoreactive perikarya in the arcuate nucleus. B. Dynorphin A immunoreactive perikarya in the supraoptic nucleus. C. Leu-enkephalin immunoreactive perikarya in the periventricular nucleus. Note that in each case the immunoreactive perikarya are slightly below the plane of focus in order to focus on the $\left[{ }^{3} \mathrm{H}\right]$ thymidine autoradiographic grains in the overlying emulsion. Note also the presence of autoradiographic grains over the nucleus of both "stained" and "unstained" perikarya. The grain density over the stained neurons is categorized as heavy or medium (H/M) and light or unlabelled (L/U). Magnification: $362 \times$ nucleus (Fig. 1C), ventromedial nucleus, medial mammil. lary nucleus, and other scattered cells in the preoptic area, as well as the perifornical region in the lateral hypothalamic area. The counted cells were divided into two categories: heavy or medium labelled (H/M: approximately 15 or more grains per nucleus), and light or unlabelled $(\mathrm{L} / \mathrm{U}$ : approximately $\mathbf{0}-\mathbf{1 0}$ grains per nucleus), according to the density of silver grains over the cell nucleus (see Fig. 1). Only those immunoreactive perikarya that had a well-defined nucleus were included in the counts. The results were expressed as percentages of $\mathrm{H} / \mathrm{M}$-labelled immunoreactive cells compared to the total number of immunoreactive cells (i.e., $[\mathrm{H} / \mathrm{M} \div \mathrm{H} / \mathrm{M}+\mathrm{L} / \mathrm{U}] \times 100$ ) in each particular nucleus or area. These calculated values represented the percentage of $\left[{ }^{3} \mathrm{H} \mid\right.$ thymidine-labelled immunoreactive cells at any given gestational day E12-E16. Since only those cells undergoing their final mitotic division exhibit $\mathrm{H} / \mathrm{M}$ labelling, this method of calculation indicates the percentage of all immunoreactive cells which originated (i.e., were "born") on the day of $\left[{ }^{3} \mathrm{H}\right]$ thymidine injection. All slides were coded prior to counting to eliminate experimental bias. The statistical significance of changes in the percentage of cells incorporating $\left[{ }^{3} \mathrm{H}\right]$ thymidine, across days, was evaluated by analysis of variance. Values of $F$ corresponding to $p$ values of less than .05 were taken to indicate statistical significance.

\section{RESULTS}

In the adult brain, neuronal perikarya immunoreactive for ACTH, dynorphin A, and leu-enkephalin were noted in several hypothalamic and preoptic nuclei and areas. ACTH immunoreactive neurons were located within the arcuate nucleus and periarcuate region in the medial-basal hypothalamus (Fig. 1A). Dynorphin A immunoreactivity was seen in magnocellular supraoptic (Fig. 1B) and paraventricular perikarya as well as scattered neurons in the lateral hypothalamic area. Leu-enkephalin perikarya were localized to several hypothalamic nuclei, including the periventricular (Fig. 1C), ventromedial, and medial mammillary nuclei, and scattered in the perifornical region at the level of the paraventricular nucleus, as well as in the medial preoptic area.

$\left[{ }^{3} \mathrm{H}\right]$ thymidine labelling appeared in the form of autoradiographic grains over the nuclei of immunoreactive neurons as well as other nonimmunoreactive neurons (see Fig. 1). However, only immunoreactive neurons with distinct rounded nuclei with or without labelling were included in the data collection. Autoradiographic analyses of immunoreactive neurons in the hypothalami of rats exposed in utero to $\left[{ }^{3} \mathrm{H}\right]$ thymidine at embryonic days $\mathrm{E} 12, \mathrm{E} 13, \mathrm{E} 14$, E15, or E16 revealed the following results:

The ACTH-containing neurons of the arcuate nucleus showed a heavy nuclear-labelling pattern at very early stages of development (Fig. 2). More than 50\% of ACTH immunoreactive cells incorporated H/M label on days E12 and E13. From E14 through E16, a gradual drop in nuclear labelling occurred, with very low levels seen at E16.

Among the three groups of dynorphinergic neurons, the patterns of labelling in the supraoptic and paraventricular nuclei appeared to be similar; i.e., in both nuclei, the dynorphin A immunoreactive magnocellular neurons exhibited peak heavy labelling with $\left[{ }^{3} \mathbf{H}\right]$ thymidine on embryonic day E13 (Figs. 3, 4). By day E14, the majority of cells (more than $80 \%$ ) were already born, with minimal labelling occurring at days E15 and E16. In contrast, the immunoreactive 


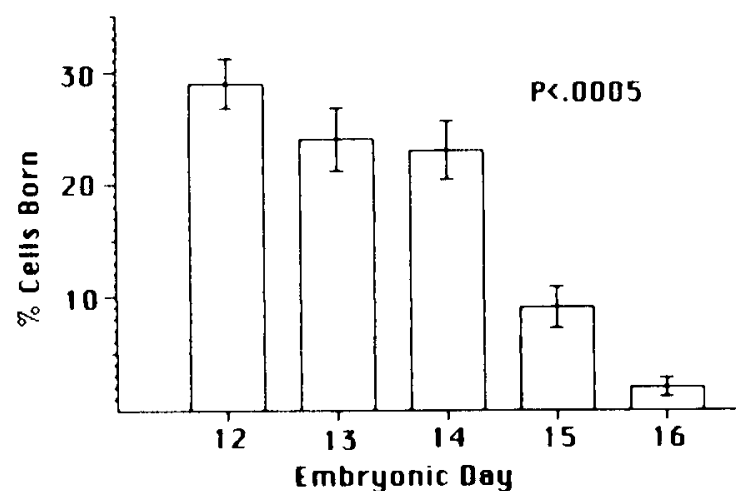

Fig. 2. Time course of ACTH (POMC) neuron genesis in the arcuate nucleus. Note heavy $\left[{ }^{3} \mathrm{H} \mid\right.$ thymidine labelling (\% cells born) on days E12E14. $N=2,266$. Mean \pm S.E.M. In this and subsequent figures, probability (p) values were determined by analysis of variance of percentages acros days, while $\mathrm{N}$ indicates the total number of immunoreactive cells counted.

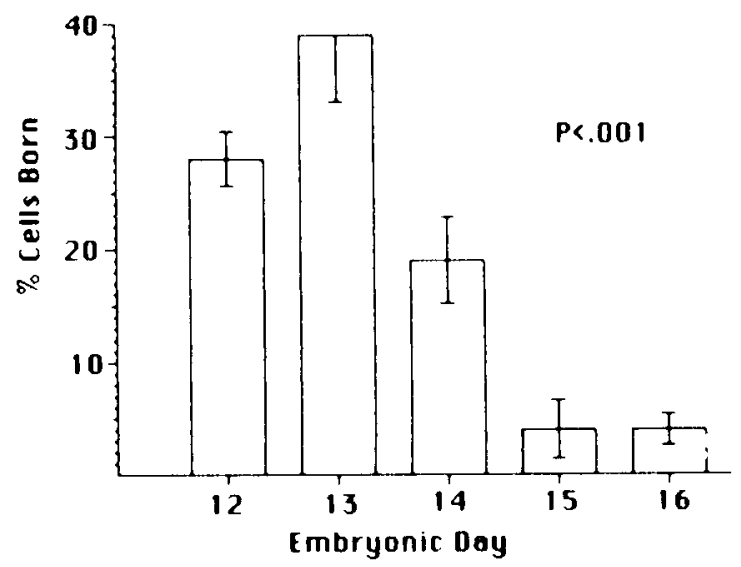

Fig. 4. Time course of genesis of dynorphin A neurons in the paraventricular nucleus. Note that the pattern of cell birth in this nucleus corre. sponds closely to the pattern observed for the supraoptic nucleus. $N=$ 1,505. Mean \pm S.E.M.

dynorphin perikarya in the lateral hypothalamus demonstrated a labelling pattern similar to that of arcuate ACTH neurons, with the heaviest nuclear $\left[{ }^{3} \mathrm{H}\right]$ thymidine labelling occurring on days E12 and E13 (more than 50\%) (Fig. 5). A gradual decline in labelling was similarly noted between days E14 and E16 (no labelling at E16).

Leu-enkephalin-containing neurons scattered in five separate nuclei or regions exhibited diverse $\left[{ }^{3} \mathrm{H}\right]$ thymidinelabelling patterns of their nuclei. In the periventricular nucleus, enkephalinergic perikarya exhibited peak heavy labelling on embryonic day E14 (approximately 25\%), with the majority of the remainder of labelling occurring on days E12 and E13 (approximately 25\%) (Fig. 6). Very little label was detected on days E15 and E16. Enkephalin-containing neurons of the ventromedial nucleus were labelled most heavily on day E13 (approximately 24\%), with the majority of the remainder of labelling occurring on embryonic days E14 and E15 (over 35\%) (Fig. 7). In the medial mammillary

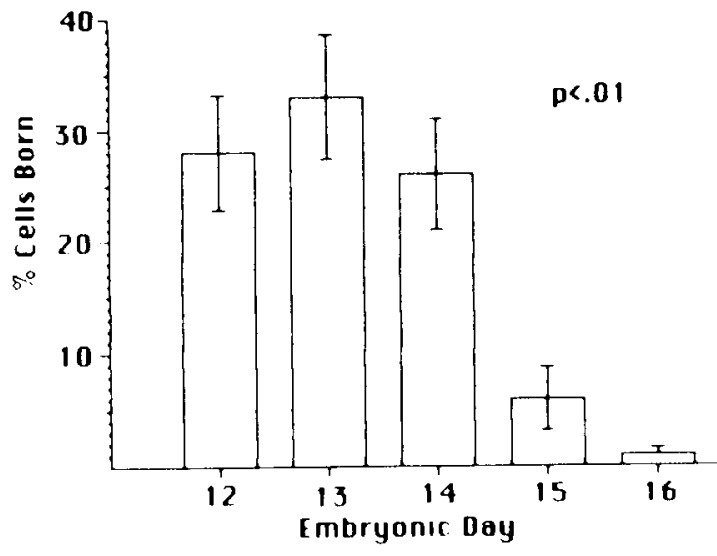

Fig. 3. Time course of dynorphin A neuron genesis in the supraoptic nucleus. Note peak heavy labelling of $\left.\right|^{3} \mathrm{H} \mid$ thymidine (\% cells born) on day E13. $N=1,345$. Mean \pm S.E.M

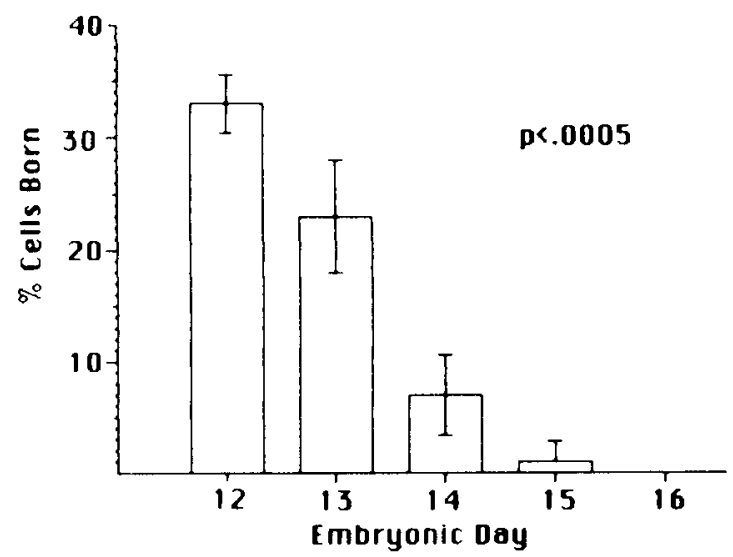

Fig. 5. Time course of dynorphin A neuron genesis in the lateral hypo. thalamic area. These neurons are born relatively early as indicated by heavy $\left[{ }^{3} \mathrm{H}\right.$ thymidine labelling (\% cells born) on days $\mathrm{E} 12$ and $\mathrm{E} 13$, respectively. $\mathrm{N}=1,197$. Mean \pm S.E.M

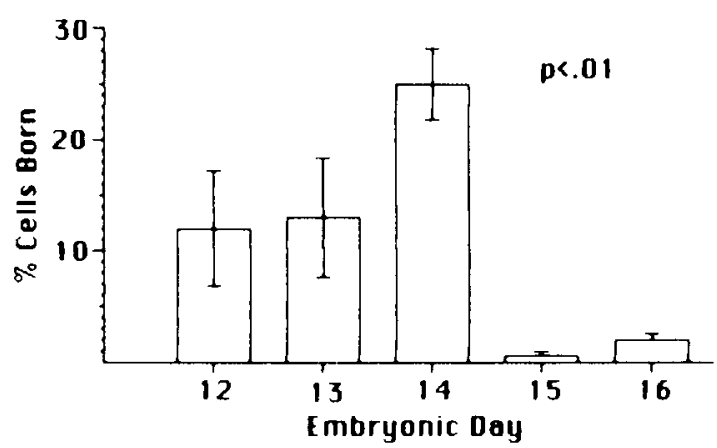

Fig. 6. Time course of leu-enkephalin neuron genesis in the periventric ular nucleus. Note peak heavy $\left[{ }^{3} \mathrm{H}\right.$ thymidine labelling (\% cells born) on day $\mathbf{E} 14 . \mathbf{N}=967$. Mean + S.E.M. 


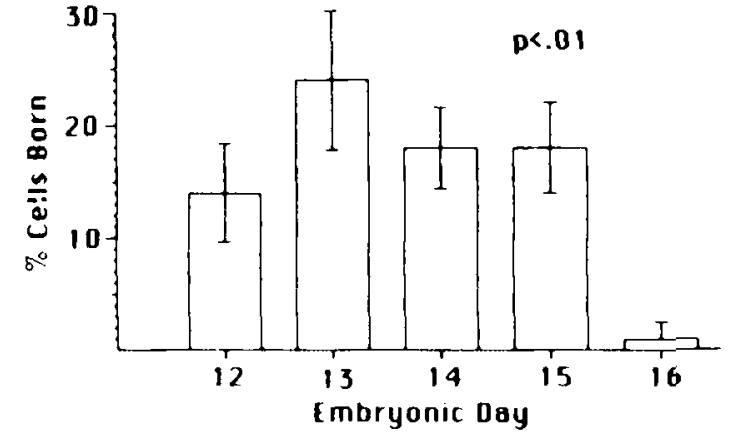

Fig. 7. Time course of genesis of leu-enkephalin neurons in the ventromedial nucleus. Note that while peak heavy $\left[{ }^{3} \mathrm{H} \mid\right.$ thymidine labelling $(\%$ cells born) is on day E 13 , significant labelling is also seen on days $\mathrm{E} 12, \mathrm{E} 14$, and E15. $\mathrm{N}=718$. Mean \pm S.E.M

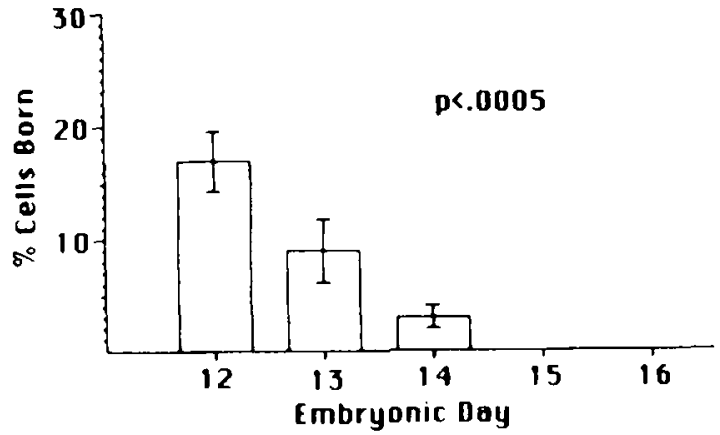

Fig. 9. Time course of genesis of leu-enkephalin neurons in the perifornical hypothalamic area. Note the sharp decline in $\left[{ }^{3} \mathrm{H}\right]$ thymidine labelling (\% cells born) from E12 through E14, with zero labelling on the subsequent days studied. $\mathrm{N}=557$. Mean \pm S.E.M.

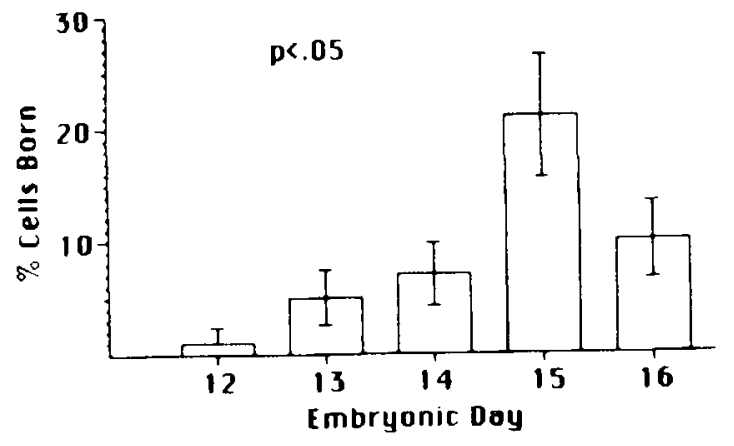

Fig. 8. Time course of leu-enkephalin neuron genesis in the medial mammillary nucleus. Note peak heavy $\left[{ }^{3} \mathrm{H}\right]$ thymidine labelling (\% cells born) on day E15 with minimal labelling on days E12-E14. $\mathrm{N}=847$. Mean + S.E.M.

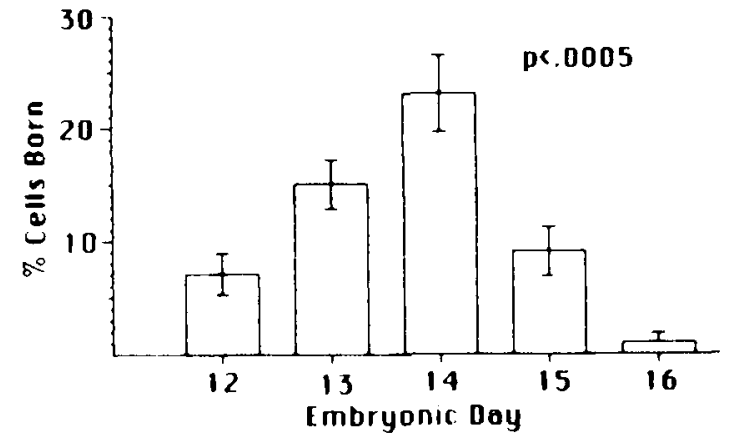

Fig. 10. Time course of leu-enkephalin neuron genesis in the medial preoptic area. Note peak heavy $\left[{ }^{3} \mathrm{H}\right.$ thymidine labelling ( $\%$ cells born) on day $E 14 . N=1,343$. Mean \pm S.E.M nucleus, the enkephalin perikarya exhibited the most unusual labelling pattern of all the groups studied. In this nucleus, the majority of immunoreactive enkephalinergic neurons were heavily labelled on days E14-E16 (approximately $38 \%$ ), with peak heavy labelling occurring on E15 (Fig. 8). Minimal heavy labelling was seen on days E12 and E13. Enkephalin-containing perikarya scattered in the perifornical region showed a dramatic decline of heavy labelling following day E12 (approximately 17\%) (Fig. 9). All of the remainder of labelling occurred on days E13 and E14, with no labelling noted on days E15 and E16. Lastly, in the medial preoptic area, scattered immunoreactive enkephalinergic neurons exhibited peak heavy labelling on day E14 (approximately 23\%) with gradually declining heavy labelling seen both before and after that day (Fig. 10). Still, the majority of heavy labelling in this region occurred between E13 and E15 (over 35\%).

\section{DISCUSSION}

In the present study, we have investigated the development of opioid peptidergic neurons in the rat hypothalamus. These neurons are represented by ACTH, dynorphin $A$, and leu-enkephalin immunoreactivity localized to neuronal perikarya of colchicine-pretreated young adult ani- mals. These three immunoreactivities are markers for the three separate opioid precursors present in neural tissue (Nakanishi et al., '79; Comb et al., '82; Noda et al., '82; Gubler et al., ' 82 ; Kakidani et al., ' 82 ). The distribution of peptides derived from these precursors has been studied extensively in the central nervous system. These include POMC-derived peptides (Watson et al., '78a,b; Bloch et al., '78; Bloom et al., '78; Zimmerman et al., '78; Nilaver et al., '79; O'Donohue et al., '79; Finley et al., '81; Khachaturian et al., '85), proenkephalin-derived peptides (Elde et al., '76; Watson et al., '77, ' $82 \mathrm{~b}$; Hökfelt et al., '77; Sar et al., '78; Khachaturian et al., ' $83 \mathrm{~b}, \mathrm{c}$ ), and prodynorphin-derived peptides (Waston et al., '81, '82a,b, '83; Khachaturian et al., '82; Vincent et al., '82; Weber et al., '82). The antisera used in the present study have been extensively characterized elsewhere (Watson et al., '78b; Khachaturian et al., ' 82 , ' $83 \mathrm{~b}$ ).

In order to determine the onset of neuron differentiation, the animals in this study were exposed in utero to a brief pulse of $\left[{ }^{3} \mathrm{H}\right]$ thymidine on specific days during the embry. onic period. According to Sidman ('70), $\left[{ }^{3} \mathrm{H}\right]$ thymidine given as a pulse injection is incorporated within 20-40 minutes into cell nuclei. In the present study, the $\left[{ }^{3} \mathrm{H}\right]$ thymidineexposed rats were allowed to develop into young adults, so that the neurons in question would be mature, hypotha- 
lamic nuclear boundaries well defined, and the animal could reliably be treated with colchicine to enhance perikaryal immunoreactivity. This treatment greatly enhances the reliability of the cell counts, since without colchicine administration, perikaryal immunoreactivity is not as pronounced with every antiserum used.

Some of the observed patterns of cell birth seen in the present study show good correspondence with other studies of the ontogeny of opioid peptides, while others do not. For example, the observation here that ACTH-containing neurons exhibit heaviest labelling in the earliest gestational period studied (E12-E13) agrees well with the detection of immunoreactive ACTH, $\beta$-endorphin, and other POMC products early in embryonic development. We and other investigators have noted immunoreactive POMC cells in the medial-basal hypothalamus as early as embryonic day E12 (Schwartzberg and Nakane, '82; Khachaturian et al., '83a) or E13.5 (Daikoku et al., '83). While the methods for determining the age of the embryos vary slightly among the latter studies, nevertheless, there is good consensus that POMC neurons are among the earliest arising of the opioid peptide neurons.

Dynorphin-containing magnocellular neurons are not detectable with immunocytochemistry until gestational day E18 (Khachaturian et al., '83a). Dynorphin neuronal perikarya first appear in the region of the supraoptic nucleus during late gestation. However, we have been able to detect dynorphin $A$ immunoreactive fibers in the neural lobe of the pituitary at day E17. The presence of immunoreactivity in the neural lobe alone would argue for the synthesis of dynorphin in magnocellular neurons at an even earlier gestational day (i.e., prior to E17). That magnocellular neurons are biosynthetically active at this stage of development has also been demonstrated by studies showing neurophysin immunoreactivity as early as day E14 of gestation (Sinding et al., '80). Nevertheless, the observed im munoreactivity does not correspond well with the present autoradiographic determination of the time of origin of these neurons (E12-E14). This can perhaps be explained by a time lag between neuron birth and the initiation of neuropeptide precursor synthesis, and also by the notion that peptide concentration at such an early stage might be below the level of detection by immunocytochemistry. Generally, radioimmunoassay offers a more sensitive means for measuring minute quantities of peptide during early gestation. Such data are not yet available for dynorphin peptides. Still another consideration is the specificity of the antiserum used. It is conceivable that if the posttranslational processing mechanisms are immature, most if not all peptides synthesized at an early stage may be in precursor form such that they are not easily detected by the antibody (i.e., low antigenicity). Thus, as more and more cells are born and begin to mature, sufficient quantities of free peptide may become available for detection. In this context, it is interesting to note that even in the case of POMC neurons of the arcuate nucleus, the best observed immunoreactivity at a very early gestational period (E12) is obtained using a $16 \mathrm{~K}$ antiserum ( $\mathrm{N}$-terminus of POMC precursor), with $\mathrm{ACTH}$ and $\beta$-endorphin antisera showing less immunoreactivity, and with $\alpha$-MSH antiserum showing no immunoreactivity at all (Khachaturian et al., '83a). Perhaps the use of dynorphin antisera directed against specific portions of the prodynorphin precursor will likewise enable its earlier detection in the embryo. Of course, the above arguments do not rule out the possibility that dynorphin synthesis in magnocellular neurons might begin late in gestation. These neurons also produce arginine-vasopressin (cf. Watson et al., '82a), a hormone which may be important at an earlier stage of development (see Swaab and Ter Borg, '81).

The pattern of differentiation of leu-enkephalin-containing neurons in the various hypothalamic and preoptic regions is also indicative of neuron birth several days prior to the detection of immunoreactivity. Here, clearly, neurons arise at different stages of development in different nuclei. For example, immunoreactive leu-enkephalin neurons in the perifornical region and ventromedial nucleus arise early (E12-E14); those in the periventricular nucleus and medial preoptic area arise relatively later (E13-E15); while those neurons in the medial mammillary nucleus (E14-E16) arise the latest of all cell groups examined. By contrast, most immunocytochemical studies of enkephalin have described immunoreactive perikarya in the fetus at gestational days E17-E18 (Pickel et al., '82; Palmer et al., '82; Khachaturian et al., '83a). Nevertheless, enkephalin fiber immunoreactivity has been noted at E15-E16 in the three studies mentioned above. These observations indicate biosynthesis of enkephalin at an earlier stage, with perikaryal levels too low to be detected by immunocytochemistry. Similarly, enkephalin immunoreactivity has been detected by radioimmunoassay at E16, the earliest gestational day studied so far (Bayon et al., '79). Again, as suggested for dynorphin, it is possible that there is a time lag between neuron birth and initiation of enkephalin synthesis. Moreover, enkephalin at an early embryonic stage might be present in precursor form, and thus not be as easily detectable with the present antiserum. In fact, most of the previous discussion pertaining to the genesis and differentiation of dynorphin neurons might also apply to enkephalin neurons as well. Thus, the use of antisera raised against various specific areas of the proenkephalin molecule might prove useful in the dectection of precursor forms at earlier gestational days in concordance with the observed patterns of cell birth.

Previous $\left[{ }^{3} \mathrm{H} \mid\right.$ thymidine autoradiographic studies of hypothalamic nuclear development, utilizing Nissl-stained material, have demonstrated that there exist specific patterns that govern the generation of neurons in different zones within the hypothalamus (Ifft, '72; Altman and Bayer, '78a). Ifft ('72) has suggested that laterally placed neurons arise earlier than those situated in more medial nuclei. In addition to this lateral-to-medial gradient of hypothalamic neuron genesis, which apparently is contrary to patterns seen elsewhere in the brain (see Jacobson, '78; chapter 3), there also appears to be a dorsal-to-ventral gradient of neurogenesis (Ifft, '72). Based on their more comprehensive labelling studies, Altman and Bayer ('78a) have further refined these gradients of hypothalamic neuron birth into four chronologically different classes, within each of which neuron genesis appears to be isochronous. Of interest to us, for purposes of this paper, are class 1 (earliest arising) neurons in the lateral hypothalamic area, class 2 (early arising) neurons in the supraoptic and paraventricular nuclei and medial preoptic area, and class 3 (late arising) neurons in the arcuate, ventromedial, periventricular, and medial mammillary nuclei (Altman and Bayer, '78a). We have observed no opioid peptide-containing neurons belonging to the latest-arising class 4 cells. In correlating the present findings to those of Altman and Bayer ('78a), it is important to note that the two studies have used different 
methods of determining the embryonic age at which time $\left[{ }^{3} \mathrm{H}\right]$ thymidine was made available to the growing embryos. In the present study, day of coitus (i.e., detection of sperm in vaginal smear) has been designated day zero of gestation, while Altman and Bayer ('78b) have considered day of coitus as day 1 of gestation. Thus, E13-E17 of the latter study correspond to days E12-E16 used in the present study. For simplicity, we shall hereafter use E12 through E16 when referring to either study. Furthermore, when used, the designation class 1-4 neurons will be in reference to the findings of Altman and Bayer ('78a).

In general, we have noted a good correspondence between the present findings and those of Altman and Bayer ('78a) (Table 1). The earliest-arising lateral hypothalamic dynorphin A neurons (56\% at E12/E13) and perifornical leu-en kephalin neurons (26\% at E12/E13) fit into the class 1 category. The early-arising magnocellular neurons in both the supraoptic (86\% at E12-E14) and paraventricular $(87 \%$ at E12-E14) nuclei can be designated as class 2 neurons. However, this correspondence is not a sharp one, perhaps since the present study deals only with vasopressin-dynorphin-producing neurons (Watson et al., '82a) and not oxyto cin neurons. Whether there are differences in the birth patterns of vasopressin versus oxytocin neurons is currently unknown. Other early-arising neurons observed in the present study include the leu-enkephalin neurons situated in the medial preoptic area (45\% at E12-E14) and periventricular nucleus (50\% at E12-E14), which accordingly fall into the class 2 category. The time of birth of periventricular neurons was not determined in the study of Altman and Bayer ('78a).

In the late-arising category, mention should be made of leu-enkephalin neurons in the medial mammillary nucleus (38\% at E14-E16) as well as the ventromedial nucleus $(61 \%$ at E13-E15), corresponding to class 3 neurons. Once again, the exact patterns of labelling seen in the present study do not match precisely the patterns reported by Altman and Bayer ('78a). For example, in the ventromedial nucleus, peak heavy labelling of leu-enkephalin neurons occurs at E13. In contrast, Altman and Bayer (78a) have differen- tiated between ventral and dorsal regions of the ventromedial nucleus. Although the present study has not made that distinction, we believe that the patterns of leu-enkephalin cell birth in ventromedial nucleus match more closely with the class 3 neurons situated in the dorsal aspects of this nucleus.

Lastly, the patterns of cell birth seen in the POMC cell group situated in the arcuate nucleus show an inverse correspondence with those of class 3 and 4 arcuate neurons, which are among the late and latest born in the hypothalamus, respectively. By contrast, ACTH immunoreactive neurons in the arcuate nucleus were labelled heavily early and belong to the earliest-arising hypothalamic neurons (76\% at E12-E14). This is a remarkable finding, since it demonstrates a clear difference between the POMC neurons and other neurons in the arcuate nucleus in terms of time of origin. This finding is further supported by immunocytochemical observations of peptide immunoreactivity very early in arcuate POMC neurons, i.e., days E12-E13.5 (Schwartzberg and Nakane, '82; Khachaturian et al., '83a; Daikoku et al., ' 83 ). This discrepancy can perhaps be explained by the fact that POMC neurons compose a minor portion of the total number of neurons in the arcuate nucleus, such that their numbers might not make a statistically significant contribution to the labelling pattern seen when considering the entire neuronal population of this nucleus. A similar observation has been made by Hoffman et al. ('80), who have noted that somatostatin-containing neurons in the periventricular nucleus arise earlier than many of the other neurons in the same region.

In conclusion, it is apparent that a general, yet not precise correspondence exists between the patterns of opioid neuron generation and those patterns noted for whole hypotha. lamic nuclei in which the opioid neurons reside. The observation that the percentage of labelled opioid neurons at any particular day (or period of 2-3 days) is lower than those percentages obtained by Altman and Bayer ('78a) for the same time period is due to the fact that in the latter study, $\left[{ }^{3} \mathrm{H}\right]$ thymidine injections were made on 2 consecutive days, thus increasing the $\mathrm{I}^{3} \mathrm{H} \mid$ thymidine exposure time.

TABLE 1. Comparison Between the Time of Neuron Origin Determined for Each Nucleus by Altman and Bayer ('78a), and for Identified Opioid Neurons in the Present Study ${ }^{1}$

\begin{tabular}{|c|c|c|c|c|c|c|c|}
\hline \multirow[b]{2}{*}{ Category } & \multirow[b]{2}{*}{ Nucleus } & \multirow[b]{2}{*}{ Study } & \multicolumn{5}{|c|}{ Percentage cells born at each embryonic day } \\
\hline & & & E12 & E13 & E14 & E15 & E16 \\
\hline \multirow{3}{*}{$\begin{array}{l}\text { Class 1 } \\
\text { (earliest } \\
\text { arising) }\end{array}$} & \multirow[t]{3}{*}{ LHA } & Whole region & 50 & 20 & 10 & - & - \\
\hline & & Dynorphin & 33 & 23 & 7 & 1.8 & - \\
\hline & & Enkephalin (PF) & 17 & 9 & 3 & - & - \\
\hline \multirow{8}{*}{$\begin{array}{l}\text { Class } 2 \\
\text { (early } \\
\text { arising) }\end{array}$} & \multirow[t]{2}{*}{ SON } & Whole nucleus & 35 & 31 & 30 & - & - \\
\hline & & Dynorphin & 28 & 39 & 19 & 4 & 4 \\
\hline & \multirow[t]{2}{*}{ PVN } & Whole nucleus & 18 & 35 & 38 & - & - \\
\hline & & Dynorphin & 28 & 33 & 26 & 6 & - \\
\hline & \multirow[t]{2}{*}{ POA } & Medial part & 20 & 25 & 45 & 5 & - \\
\hline & & Enkephalin & 7 & 15 & 23 & 9 & 1 \\
\hline & \multirow[t]{2}{*}{ PV } & - & \multicolumn{5}{|c|}{ Data not available } \\
\hline & & Enkephalin & 12 & 13 & 25 & 0.6 & 2 \\
\hline \multirow{6}{*}{$\begin{array}{l}\text { Class } 3 \\
\text { (late } \\
\text { arising) }\end{array}$} & \multirow[t]{2}{*}{ VM } & Dorsal part & - & 20 & 55 & 19 & 10 \\
\hline & & Enkephalin & 14 & 24 & 19 & 18 & 1 \\
\hline & \multirow[t]{2}{*}{ MM } & Whole nucleus & - & 9 & 77 & - & - \\
\hline & & Enkephalin & 1.5 & 5 & 7 & 21 & 10 \\
\hline & \multirow[t]{2}{*}{$\mathrm{ARC}$} & Middle level & 15 & 10 & 45 & 20 & 10 \\
\hline & & ACTH & 29 & 24 & 23 & 9 & 2 \\
\hline
\end{tabular}

${ }^{1}$ Data on opioid neurons is taken from the histograms shown in Figures 2-10, while whole nuclear data have been approximated from Altman and Bayer ( 78 a). ARC, arcuate nucleus; LHA, lateral hypothalamic area; MM, medial mammillary nucleus; POA, preoptic area; PF, perifornical cells; PV, periventricular nucleus; PVN, paraventricular nucleus; SON, supraoptic nucleus; VM, ventromedial nucleus. 
Based on the present findings as well as those of Hoffman et al. ('80), it is apparent that precise determinations of birthdates of chemically identified neurons can only be accomplished by combined immunocytochemical and $\left[{ }^{3} \mathrm{H}\right]$ thymidine autoradiographic studies, and cannot simply be inferred by extrapolation from whole nuclear studies. Obviously, birth-dating nuclei that are made up of one type of cell, e.g., the magnocellular portions of supraoptic and paraventricular nuclei, as well as the locus coeruleus (Lauder and Bloom, '74), is not a major problem. Conversely, the finding of early POMC neuron birth as well as early POMC peptide synthesis in a small subpopulation of arcuate neurons (Khachaturian et al., '83a) indicates the need for such combined analyses.

The early development of biosynthetically active POMC neurons may indicate an important role for POMC peptides during a stage of development in which other peptides have not yet appeared. POMC products, especially $\alpha$-MSH, have been shown to stimulate nerve cell maturation, perhaps being one of the more important neurotrophic factors during embryogenesis (see Swaab and Ter Borg, ' 81 ). The present findings appear to be consistent with this hypothesis. Furthermore, the finding that neither enkephalin nor dynorphin neurons appear to arise at precisely the same time indicates that neuron genesis in different regions of the hypothalamus proceeds according to specific timetables, influenced by regulatory mechanisms which apparently work irrespective of the peptide product.

\section{ACKNOWLEDGMENTS}

This work was supported by the T. Raphael research fund, NIDA grant DA02265, and NIMH grant MH36851 to S.J.W. and H.K., and by NIMH training grant MH15794 to M.E.L. We wish to thank J.M. Roberts-Lewis, M. Fitzsimmons, and P. Quinlan for technical assistance and E. Romkema for manuscript preparation.

\section{LITERATURE CITED}

Alessi, N.E., and H. Khachaturian (1985) Postnatal development of betaendorphin immunoreactivity in the medulla oblongata of rat. Neuropeptides $5: 473-476$.

Alessi, N.E., H. Khachaturian, S. Watson, and H. Akil (1983) Postnatal ontogeny of acetylated and non-acetylated beta-endorphin in rat pituitary. Life Sci. 33(Suppl. I):57-60.

Altman, J., and S.A. Bayer (1978a) Development of diencephalon in the rat. I. Autoradiographic study of the time of origin and settling patterns of neurons of the hypothalamus. J. Comp. Neur. 182:945-972.

Altman, J., and S.A. Bayer (1978b) Development of the diencephalon in the rat. 1. Correlation of the embryonic development of the hypothalamus with the time of origin of its neurons. J. Comp. Neur. 182:973-994

Bayon, A., W.J. Shoemaker, F.E. Bloom, A. Mauss, and R. Guillemin (1979) Perinatal development of the endorphin- and enkephalin-containing systems in the rat brain. Brain Res. 179:93-101.

Bloch, B., C. Bugnon, D. Fellman, and D. Lenys (1978) Immunocytochemical evidence that the same neurons in the human infundibular nucleus are stained with anti-endorphins and antisera of other related peptides. Neurosci. Lett. 10:147-152

Bloom, F., E. Battenberg, J. Rossier, N. Ling, and R. Guillemin (1978) Neurons containing beta-endorphin in rat brain exist separately from those containing enkephalin: Immunocytochemical studies. Proc. Natl. Acad. Sci. USA 75:1591-1595.

Comb, M., P.H. Seeburg, J. Adelman, L. Eiden, and E. Herbert (1982) Primary structure of the human Met- and Leu-enkephalin precursor and its mRNA. Nature 295:663-666.

Coyle, J.T. (1977) Biochemical aspects of neurotransmission in the developing brain. Int. Rev. Neurobiol. 20:65-103.

Daikoku, S., M. Chikamori, T. Adachi, Y. Okamura, T. Nishiyama, and Y. Tsuruo (1983) Ontogenesis of hypothalamic immunoreactive ACTH cells in vivo and in vitro: Role of Rathke's pouch. Dev. Biol. 97:81-88.
Elde, R., T. Hökfelt, O. Johansson, and L. Terenius (1976) Immunohisto chemical studies using antibodies to leucine-enkephalin: Injtial obser vations on the nervous system of the rat. Neuroscience 1:349-351.

Finley, J.C.W., P. Lindstrom, and P. Petrusz (1981) Immunocytochemical localization of beta-endorphin-containing neurons in the rat brain. Neuroendocrinology 33:28-42

Gubler, U., P. Seeburg, B.J. Hoffman, L.P. Gage, and S. Udenfriend (1982) Molecular cloning establishes proenkephalin as precursor of enkephalin-containing peptides. Nature 295:206-208.

Hoffman, G.E., L.B. Dick, and D. Gash (1980) Development of somatostatin neurons: Examination by the technique of combined autoradiography and immunocytochemistry. Peptides 1(Suppl 1):79-83.

Hökfelt, T., R. Elde, O. Johansson, L. Terenius, and L. Stein (1977) The distribution of enkephalin-immunoreactive cell bodies in the rat central nervous system. Neurosci. Lett. 5:25-31.

Ifft, J.D. (1972) An autoradiographic study of the time of final division of neurons in rat hypothalamic nuclei. J. Comp. Neur. 144:193-204.

Jacobson, M. (1978) Development Neurobiology, Second Edition. New York: Plenum.

Kakidani, H., Y. Furutani, H. Takahashi, M. Noda, Y. Morimoto, T. Hirose, M. Asai, S. Inayama, S. Nakanishi, and S. Numa (1982) Cloning and sequence analysis of cDNA for porcine beta-neo- endorphin/dynorphin precursor. Nature 298:245-249.

Khachaturian, H., N.E. Alessi, M.E. Lewis, N. Munfakh, M.D. Fitzsimmons, and S.J. Watson (1985) Development of hypothalamic opioid neurons: $\Lambda$ combined immunocytochemical and $\left[{ }^{3} \mathrm{H}\right]$ thymidine autoradiographic study. Neuropeptides, 5:477-480.

Khachaturian, H., N.E. Alessi, N. Munfakh, and S.J. Watson (1983a) Ontog eny of opioid and related peptides in the rat CNS and pituitary: An immunocytochemical study. Life Sci. 33:61-64.

Khachaturian, H., M.E. Lewis, V. Hollt, and S.J. Watson (1983b) Telencephalic enkephalinergic systems in the rat brain. J. Neurosci. 3:844-855.

Khachaturian, H., M.E. Lewis, and S.J. Watson (1983c) Enkephalin systems in diencephalon and brainstem of the rat. J. Comp. Neur. 220:310-320.

Khachaturian, H., M.E. Lewis, K. Tsou, and S.J. Watson (1985) Beta-endorphin, alpha-MSH, AC'TH, and related peptides. In T. Hökfelt and A. Björklund (eds): Handbook of Chemical Neuroanatomy, Vol. 4, Neuropeptides in the CNS. Elsevier Biomedical Publishers, Amsterdam, in press.

Khachaturian, H., and J.R. Sladek, Jr. (1980) Simultaneous monoamine histofluorescence and neuropeptide immunocytochemistry: III. Ontog eny of catecholamine varicosities and neurophysin neurons in the rat supraoptic and paraventricular nuclei. Peptides 1:77-95

Khachaturian, H., S.J. Watson, M.E. Lewis, D. Coy, A. Goldstein, and H. Akil (1982) Dynorphin immunocytochemistry in the rat central nervous system. Peptides 3:942-954.

Langager, J.M., G.A. Howard, and D.J. Baylink (1982) An improved technique for rapid autoradiography of cells and tissue sections. Histochem istry 75:523-531.

Lauder, J.M., and F.E. Bloom (1974) Ontogeny of monoamine neurons in the locus coeruleus, raphe nuclei and substantia nigra of the rat. $I$. Cell differentiation. J. Comp. Neur. 155:469-482.

Lauder, J.M., and H. Krebs (1976) Effects of p-chlorophenylalanine on time of neuronal origin during embryogenesis in the rat. Brain Res. 107:638644 .

Lauder, J.M., and H. Krebs (1978) Serotonin as a differentiation signal in early neurogenesis. Dev. Neurosci. 1:15-30.

Nakanishi, S., A. Inoue, T. Kita, M. Nakamura, A.C.Y. Chang, S.N. Cohen, and S. Numa (1979) Nucleotide sequence of cloned cDNA for bovine corticotropin-beta-LPH precursor. Nature 278:423-427.

Nilaver, G., E.A. Zimmerman, R. Defendini, A.S. Liotta, D.T. Krieger, and M.J. Brownstein (1979) Adrenocorticotropin and beta-lipotropin in the hypothalamus. J. Cell Biol. 18:50-58.

Noda, M., Y. Furutani, H. Takahashi, M. Toyosato, T. Hirose, S. Inayama S. Nakanishi, and S. Numa (1982) Cloning and sequence analysis of cDNA for bovine adrenal preproenkephalin. Nature 295:202-206.

O'Donohue, T.L., R. L. Miller, and D.M. Jacobowitz (1979) Identification, characterization and stereotaxic mapping of intraneuronal alpha-MSH like immunoreactive peptides in discrete regions of the rat brain. Brain Res. 176:101-123.

Olson, L., and A. Seiger (1972) Early prenatal ontogeny of central mono amine neurons in the rat: Fluorescence histochemical observations. Z. Anat. Entwickl. Gesch. 137:301-316.

Patey, G., S. de la Baume, C. Gros, and J.-C. Schwartz (1980) Ontogenesis of enkephalinergic systems in the rat brain: Post-natal changes in en kephalin levels, receptors and degrading enzyme activities. Life Sci. 27:245-252. 
Palmer, M.R., R.J. Miller, L. Olson, and A. Seiger (1982) Prenatal ontogeny of neurons with enkephalin-like immunoreactivity in the rat central nervous system: An immunohistochemical mapping investigation. Med. Biol. 60:61-82.

Pickel, V.M., K.K. Sumal, and R.J. Miller (1982) Early prenatal development of substance $P$ and enkephalin-containing neurons in the rat. J. Comp. Neur. 210:411-422.

Sar, M., W.E. Stumpf, R.J. Miller, K.-J. Chang, and P. Cuatrecasas (1978) Immunohistochemical localization of enkephalin in rat brain and spinal cord. J. Comp. Neur. 182:460-482.

Schwartzberg. D.G., and P.K. Nakane (1982) Ontogenesis of adrenocorticotropin-related peptide determinants in the hypothalamus and pituitary gland of the rat. Endocrinology 110:855-864.

Seiger, A., and L. Olson (1973) Late prenatal ontogeny of central monoamine neurons in the rat. Fluorescence histochemical observations. $\mathrm{Z}$. Anat. Entwickl. Gesch. 140:201-318.

Shimada, M., and T. Nakamura (1973) Time of neuron origin in mouse hypothalamic nuclei, Exp. Neurol. 41:163-173.

Sidman, R.L. (1970) Autoradiographic methods and principles for the study of the nervous system with thymidine- $\mathrm{H}^{3}$. In: W.J.H. Nauta and S.O.E. Ebbesson (eds): Contemporary Research Methods in Neuroanatomy. New York: Springer-Verlag, pp. 252-274.

Sinding, C., P. Czernichow, S.M. Seif, and A.G. Robinson (1980) Quantitative changes in neurohypophyseal peptides in the developing brain. Peptides 1 (Suppl. 1):45-50.

Swaab, D.F., and J.T. Martin (1981) Functions of alpha-MSH and other opiomelanocortin peptides in labour, intrauterine growth and brain development. In: Peptides of the Pars Intermedia. London: Pitman (Ciba Foundation Symposium 81), pp. 196-217.

Swaab, D.F., and J.P. Ter Borg (1981) Development of peptidergic systems in the rat brain. The Fetus and Independent Life. London: Pitman (Ciba Foundation Symposium 86), pp. 271-294

Vincent, S.R., T. Hökfelt, I. Christensson, and L. Terenius (1982) Dynorphin. immunoreactive neurons in the central nervous system in the rat. Neurosci. Lett. 33:185-190.

Wardlaw, S.L., and A.G. Frantz (1983) Brain beta-endorphin during pregnancy, parturition, and the postpartum period. Endocrinology 113:16641668 .

Watson, S.J., H. Akil, W. Fischli, A. Goldstein, E. Zimmerman, G. Nilaver, and T.B. van Wimersma Greidanus (1982a) Dynorphin and vasopressin: Common localization in magnocellular neurons. Science 216:85-87.

Watson, S.J., H. Khachaturian, H. Akil, D.H. Coy, and A. Goldstein (1982b) Comparison of the distribution of dynorphin systems and enkephalin systems in brain. Science 218:1134-1136.

Watson, S.J., H. Akil, V.E. Ghazarossian, and A. Goldstein (1981) Dynor phin immunocytochemical localization in brain and peripheral nervous system: Preliminary studies. Proc. Natl. Acad. Sci. USA 78:1260-1263.

Watson, S.J., H. Akil, C.W. Richard II, and J.D. Barchas (1978a) Evidence for two separate opiate peptide neuronal systems. Nature 275:226-228.

Watson, S.J., C.W. Richard III, and J.D. Barchas (1978b) Adrenocorticotropin in rat brain: Immunocytochemical localization in cells and axons. Science 200:1180-1182

Watson, S.J., H. Akil, S. Sullivan, and J.D. Barchas (1977) Immunocytochemical localization of methionine enkephalin: Preliminary observations. Life Sci. 25:733-738.

Watson, S.J., H. Khachaturian, L. Taylor, W. Fischli, A. Goldstein, and H. Akil (1983) Pro-dynorphin peptides are found in the same neurons throughout rat brain: Immunocytochemical study. Proc. Natl. Acad. Sci. USA 80:891-894

Weber, E., K.A. Roth, and J.D. Barchas (1982) Immunohistochemical distri bution of alpha-neo-endorphin/dynorphin neuronal systems in rat brain: Evidence of colocalization. Proc. Natl. Acad. Sci. USA 79:3062-3066.

Zimmerman, E.A., A. Liotta, and D.T. Krieger (1978) Beta-lipotropin in brain: Localization in hypothalamic neurons by immunoperoxidase technique. Cell Tissue Res, 186:393-398. 